\title{
Variation at the DRD4 locus is associated with wariness and local site selection in urban black swans
}

Wouter F.D. van Dongen ${ }^{1,2^{*}}$, Randall W. Robinson ${ }^{1}$, Michael A. Weston ${ }^{2}$, Raoul A. Mulder ${ }^{3}$ and Patrick-Jean Guay ${ }^{1}$

\begin{abstract}
Background: Interactions between wildlife and humans are increasing. Urban animals are often less wary of humans than their non-urban counterparts, which could be explained by habituation, adaptation or local site selection. Under local site selection, individuals that are less tolerant of humans are less likely to settle in urban areas. However, there is little evidence for such temperament-based site selection, and even less is known about its underlying genetic basis. We tested whether site selection in urban and non-urban habitats by black swans (Cygnus atratus) was associated with polymorphisms in two genes linked to fear in animals, the dopamine receptor $\mathrm{D}_{4}$ (DRD4) and serotonin transporter (SERT) genes.

Results: Wariness in swans was highly repeatable between disturbance events (repeatability $=0.61$ ) and non-urban swans initiated escape from humans earlier than urban swans. We found no inter-individual variation in the SERT gene, but identified five DRD4 genotypes and an association between DRD4 genotype and wariness. Individuals possessing the most common DRD4 genotype were less wary than individuals possessing rarer genotypes. As predicted by the local site selection hypothesis, genotypes associated with wary behaviour were over three times more frequent at the non-urban site. This resulted in moderate population differentiation at DRD4 $\left(F_{S T}=0.080\right)$, despite the sites being separated by only $30 \mathrm{~km}$, a short distance for this highly-mobile species. Low population differentiation at neutrally-selected microsatellite loci and the likely occasional migration of swans between the populations reduces the likelihood of local site adaptations.
\end{abstract}

Conclusion: Our results suggest that wariness in swans is partly genetically-determined and that wary swans settle in less-disturbed areas. More generally, our findings suggest that site-specific management strategies may be necessary that consider the temperament of local animals.

Keywords: Black swan, DRD4, Flight initiation distance, Habitat selection, SERT, Urbanisation

\section{Background}

Habitat selection has important implications for the fitness of animals [1-3]. As habitats are typically heterogeneous in terms of quality, individuals should settle in areas which maximise their survival and reproductive output. Poor habitat selection decisions can lead to insidious evolutionary or ecological traps $[4,5]$. The global proliferation of urban centres has modified the availability of many

\footnotetext{
* Correspondence: wouter.v.dongen@gmail.com

${ }^{1}$ Applied Ecology Research Group and Institute for Sustainability and

Innovation, College of Engineering and Science, Victoria University-Footscray Park Campus, PO Box 14428, Melbourne MC, VIC 8001, Australia

${ }^{2}$ Centre for Integrative Ecology, School of Life and Environmental Sciences, Faculty of Science, Engineering and the Built Environment, Deakin University, 221 Burwood Highway, Burwood, VIC 3125, Australia

Full list of author information is available at the end of the article
}

habitats [6]. One important consequence is that wildlife typically associated with natural environments may increasingly settle in urban areas near humans. Animals in such urban habitats may experience both advantages (e.g. less predation and increased resources $[7,8]$ ) and disadvantages (e.g. greater human disturbance [9]) compared to those in rural areas. Generally, animals in urban areas are typically less wary of humans than their non-urban counterparts (e.g. [10-12]). The decreased wariness of urban wildlife is often attributed to learning and habituation to non-dangerous stimuli (e.g. $[11,13])$. However, population differences in wariness could also be genetically determined, for instance via local selection on behaviours that are under genetic control (e.g. [12, 14]). In addition, if tolerance to humans is genetically-determined, genotype- 
based site selection may occur, with individuals with bold temperaments being more likely to settle in urban environments that experience higher levels of human disturbance [15-17].

The existence of consistent, individual differences in the temperament of animals (i.e. animal personalities) is well-established [18-20]. However, animal personalities may result in reduced behavioural flexibility, limiting the capacity of individuals to adapt to diverse environmental conditions. Individuals prospecting for potential breeding or feeding sites may therefore settle in habitats that best match their temperament. For example, more wary individuals may settle in areas of less human disturbance [21]. However, scant information exists on the genetic basis of temperament-based habitat selection. This is important, because temperaments may be shaped by both environmental and genetic factors [22-24]. In addition, a species' ability to adapt to changing habitats, such as the urbanisation of natural environments, may be more constrained when temperaments are at least partly under genetic control.

In recent years, growing evidence has suggested that animal temperaments are partly genetically-determined. For example, polymorphisms at the dopamine receptor $\mathrm{D}_{4}$ gene (DRD4) are often associated with variation in diverse traits such as fear, novelty seeking and body mass (e.g. [25-27], but see: $[28,29])$. DRD4 is an important component of the dopaminergic system, coding for a subtype of dopamine receptor in vertebrates [30]. Dopamine is a major neurotransmitter, and its modulation of the central nervous system accordingly affects diverse functions and behaviours [30]. Similarly, the serotonin transporter gene (SERT) is responsible for the transport of the neurotransmitter serotonin to neurons and has been linked to variation in diverse behaviours such as harm avoidance, anxiety, aggression and novelty seeking (e.g. [31-33], but see: [34]). Traditionally, these genes have been investigated in humans and laboratory animals. However, a growing number of studies has highlighted their importance in shaping the behaviour of wild populations of animals (e.g. [35-37]), including within-species colonisation of urban habitats. For example, differences in the frequencies of SERT alleles between urban and rural populations of common blackbirds (Turdus melura) suggest that genes associated with harm avoidance are under selection during urban colonisation events [29]. However, no studies have simultaneously quantified genetic and behavioural differentiation between urban and non-urban populations of animals. This information is crucial to determine whether genetic differentiation is associated with phenotypic differentiation between urban and non-urban habitats.
Here we tested for genotype- and habitat-associated differentiation in wariness towards humans of black swans (Cygnus atratus). We first quantified wariness in populations of swans at one urban and one non-urban wetland by estimating flight initiation distance [FID: the distance at which an escape response is initiated from an approaching pedestrian, a potentially-threatening stimulus, 17]. FIDs are known to have a substantial heritable component in other bird species (e.g. [38]). By collecting multiple FIDs for a large number of individual swans at the urban wetland, we first tested whether FID is a repeatable behaviour, a prerequisite for a heritable trait under genetic control $[39,40]$. Second, we genotyped 80 individuals at the DRD4 and SERT genes to test whether wary individuals were more likely to possess certain genotypes. We then collected FID and genotypic data at the non-urban population and predicted that the frequencies of genotypes associated with increased wariness was greater in the non-urban site experiencing less human disturbance.

\section{Results \\ Repeatability of FID}

As FID is positively associated with starting distance (SD: the distance from the focal individual at which the approach commenced), we regressed FID with SD across all individuals for each trial separately. We then used the residuals for each individual (ResFID) to calculate repeatability. We detected high intra-individual repeatability in ResFID (repeatability $\left.=0.61, \mathrm{~F}_{1,131}=4.132, P=0.044\right)$. The difference in ResFID between the two trials for each individual was not significantly related to both the days lapsed between trials (mean absolute difference in ResFID between trials - 10 or fewer days lapsed $=5.6 \pm 0.8 \mathrm{~m}$, more than 10 days lapsed $=$ $6.8 \pm 0.9 \mathrm{~m} ; U=1610.5, \mathrm{~N}_{<10 \text { days }}=54, \mathrm{~N}_{>10 \text { days }}=53, P=$ 0.263 ) and whether the same individual researcher approached the swan (mean difference in ResFID between trials - same researcher $=5.9 \pm 0.6 \mathrm{~m}$, different researcher $=$ $7.0 \pm 0.9 \mathrm{~m} ; \mathrm{U}=1194.5, \mathrm{~N}_{\text {same }}=94, \mathrm{~N}_{\text {different }}=43, P=0.310$ ).

\section{Characteristics of DRD4 and SERT}

The closest alignment of the swan DRD4 protein was with Anas platyrhynchos (E-value: $2 \times 10^{-104}$ ), Fulmarus glacialis (E-value: $3 \times 10^{-98}$ ) and Caprimulgus carolinensis (E-value: $3 \times 10^{-98}$; Fig. 1a). The swan SERT gene aligned with Anas platyrhynchos (E-value: $2 \times 10^{-64}$ ), Gallus gallus (E-value: $2 \times 10^{-48}$ ) and Apaloderma vittatum (E-value: $1 \times 10^{-47}$; Fig. 1b).

All individuals were monomorphic at the SERT locus for a 335 bp allele and we identified no single nucleotide polymorphisms (SNPs) in this fragment for 24 individuals. The $461 \mathrm{bp}$ fragment of DRD4 contained six variable sites, resulting in five alleles (A-E; Fig. 2a). Alleles $A$ and $B$ differed by a single synonymous SNP, while the 


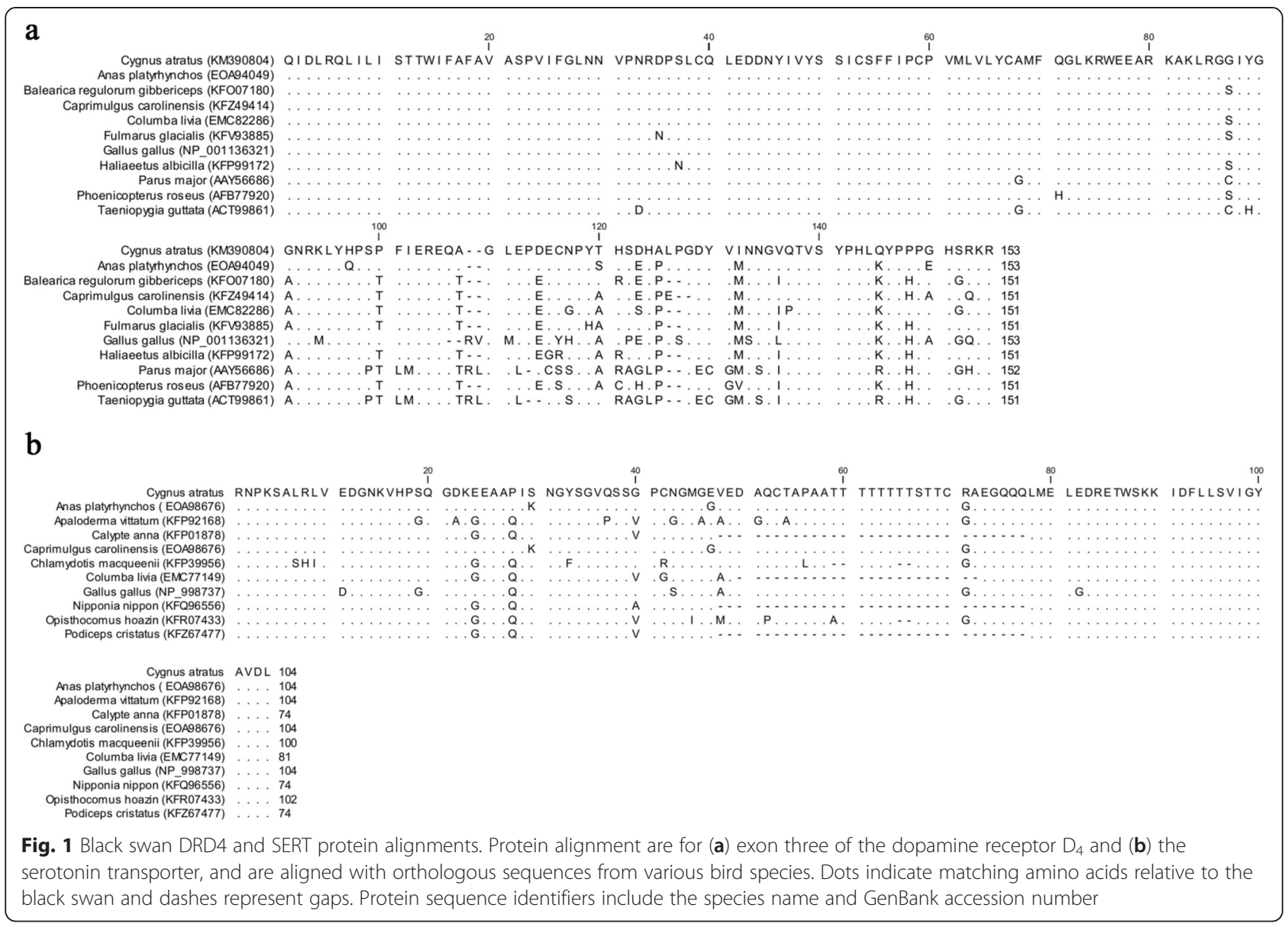

remainder of alleles differed by non-synonymous SNPs (Fig. 2b). The distribution of DRD4 genotypes was highly skewed, with $83 \%$ of individuals being homozygous at a single allele (i.e. genotype AA). The remaining individuals were either homozygous at a second allele ( $2 \%$, genotype $\mathrm{BB})$ or heterozygous $(15 \%$, genotypes $\mathrm{AB}, \mathrm{AC}$, $\mathrm{AD}, \mathrm{AE})$. Allele A was present in $98 \%$ of individuals, while the next most common allele (B) occurred in only $8 \%$ of individuals.

\section{Association between FID and genotype}

We lacked the statistical power to test for differences in mean FID between individuals with the five genotypes that were present at the urban site. To increase the power of our analyses, we therefore categorised individuals as either having the most common genotype (i.e. AA, $n=71)$ or a rare genotype $(n=9)$. Individuals with rare genotypes had longer FIDs than individuals possessing the common AA genotype (Fig. 3; Table 1). In addition, flight initiation distances were strongly positively related to starting distance, but not the focal individual's distance from water or microsatellite heterozygosity (percentage change in deviance $=14.5 \%$; Table 1).

\section{Population differences in FID and DRD4 genotypes}

Black swans were more wary at the non-urban site than at the urban site (mean starting distance - urban site = $39 \pm 2.5 \mathrm{~m}$, non-urban site $=121 \pm 12.0 \mathrm{~m}$; generalised linear model: population - Wald $\chi^{2}=64.477$, d.f. $=1, P<$ 0.001 ; year - Wald $X^{2}=18.269$, d.f. $=2, P<0.001$; location"year - Wald $\chi^{2}=35.579$, d.f. $=2, P<0.001$; starting distance - Wald $X^{2}=12.999$, d.f. $=1, P<0.001$ : Fig. 4). Overall, the mean flight initiation distance was $13 \pm$ $0.4 \mathrm{~m}$ at the urban site and $96 \pm 15.9 \mathrm{~m}$ at the nonurban site.

Forty percent of swans from the non-urban site possessed a rare genotype, compared with only $11.2 \%$ from the urban site (Fisher's exact: $p=0.005$ : Table 2). Accordingly, we detected moderate genetic population differentiation at the DRD4 locus $\left(\mathrm{F}_{\mathrm{ST}}=0.080, P<0.001\right)$. The $\mathrm{F}_{\mathrm{ST}}$ based on microsatellite loci indicated low neutral genetic differentiation between the urban and nonurban sites $\left(\mathrm{F}_{\mathrm{ST}}=0.015, P=0.002\right)$.

\section{Discussion}

The repeatability estimate of flight initiation distances in black swans was high and very similar to previous estimates in other species (e.g. [35, 38]). As repeatability in 


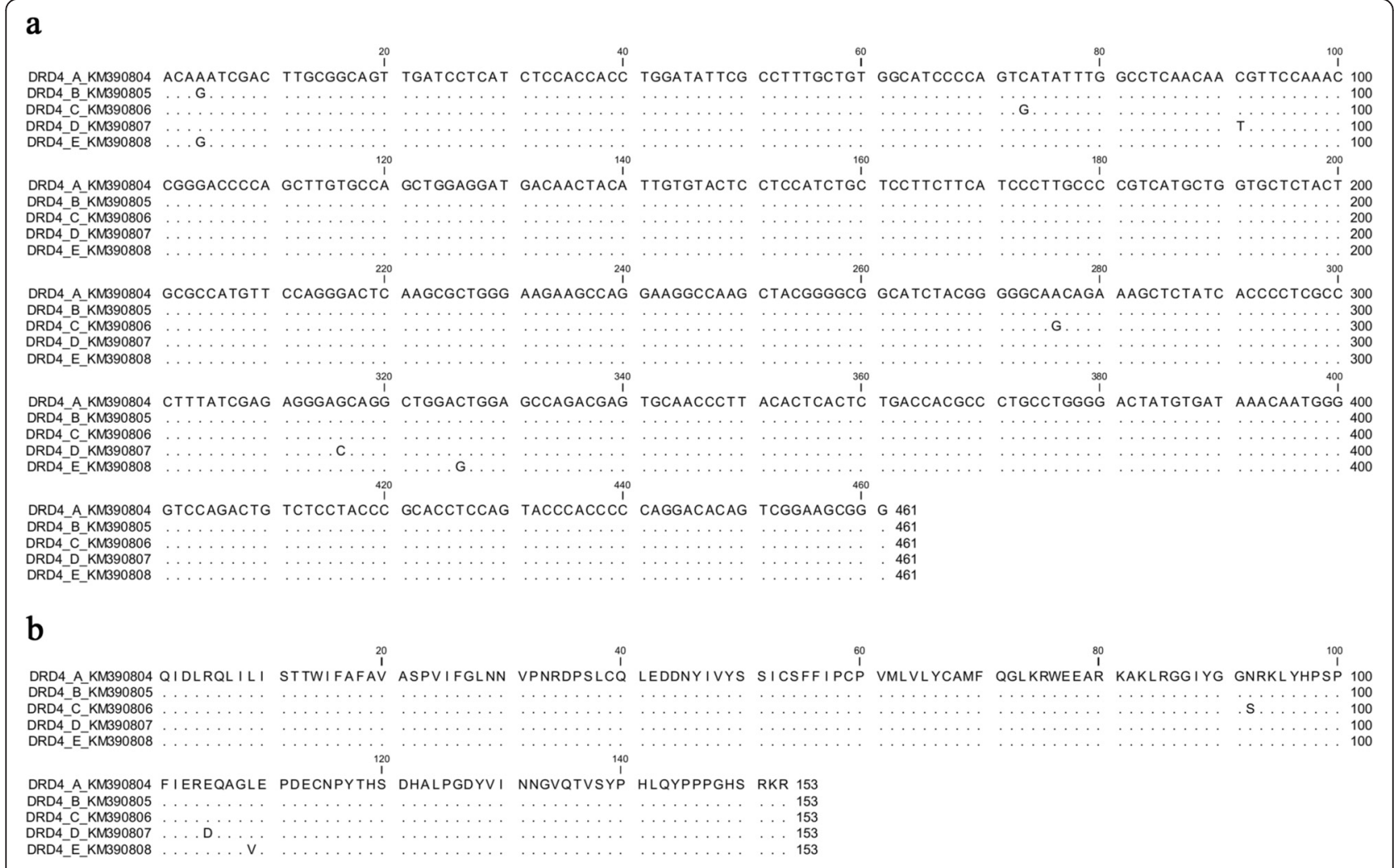

Fig. 2 DRD4 alignment for black swans. Alignments are for (a) nucleotides and (b) amino acids of exon three of the dopamine receptor $D_{4}$. Dots indicate matching nucleotides or amino acids relative to allele A. Allele identifiers include the allele name and GenBank accession number

a trait sets the upper limit for its heritability [39, 40], this suggests that FIDs may have a substantial heritable component. In support of this, we have shown here that wariness in black swans is associated with polymorphisms at the DRD4 gene. The $83 \%$ of individuals that possessed the most abundant AA genotype displayed shorter flight initiation distances than swans possessing rarer genotypes. In contrast, we found no variation in the length of exonic codon repeats located within the SERT gene. This contrasts with a previous study on common blackbirds, which detected low levels of interpopulational variation at the SERT gene but at a much larger geographic scale than in the present study [29]. We found clear population differences in FIDs, with swans from the urban wetland initiating flight $83 \mathrm{~m}$ closer than those sampled at the non-urban wetland, where less human disturbance occurs. Finally, we detected moderate differentiation at the DRD4 gene despite the sites being separated by only $30 \mathrm{~km}$, a relatively short distance for this highly-mobile species [41]. This pattern arose due to the greater proportion of swans at the non-urban site possessing rare DRD4 genotypes, which were associated with greater wariness. Although population differences in wariness to humans may arise due to multiple factors, our data suggest that they may also, at least in part, be explained by genotype-based site selection.

As the data for this study were collected from the urban and non-urban sites in different years, an effect of year on site differences in FID could not be excluded. However, it is unlikely that year differences could have driven the results reported here. First, the greater wariness of non-urban birds is well-documented [17] and the differences in wariness of the two swan populations appears to be temporally stable. In addition, a long-term capture study at the urban site $[42,43]$ suggests that at least this population is largely resident and, as such, significant reversals of DRD4 allelic frequencies are unlikely.

We do not know how variation at the DRD4 gene translates into differences in wariness in swans. SNPs detected in this study presumably alter the functionality of the dopamine receptor D4 and its affinity to dopamine. In turn, the modulation of dopamine signalling in the brain regulates multiple traits, including fear (e.g. [26]). The pleiotropic effects of DRD4 suggest that swans with different genotypes may also vary in other traits, such as exploratory behaviour (e.g. [37, 44]), novelty seeking (e.g. [35]) or body condition (e.g. [36]). Alternatively, linkage disequilibrium may result in the SNPs detected in this 


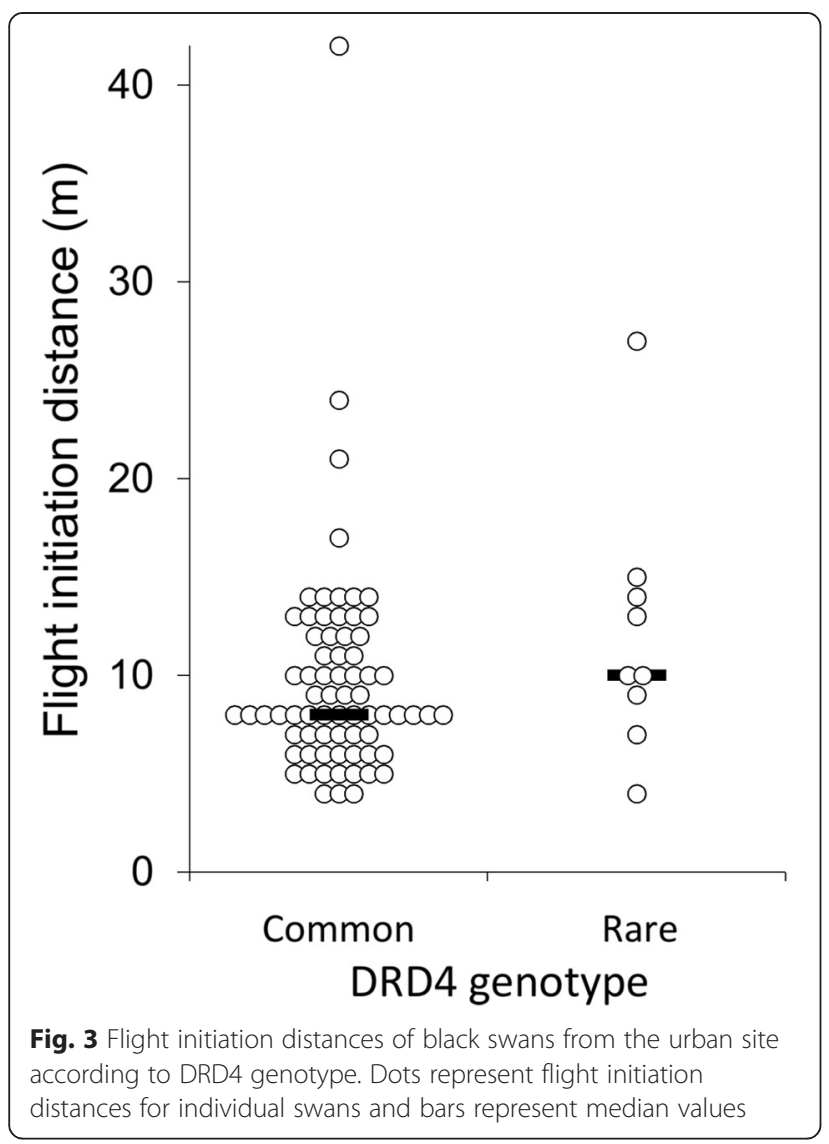

study being linked to SNPs at other genes which also regulate fear, such as the SERT gene.

The high frequency of the AA genotype, which was associated with the shortest FIDs, suggests that selection may favour the AA genotype in the study populations. This is despite the advantages of displaying high levels of wariness towards potential predators [45]. Selection may favour shorter FIDs when increased vigilance and wariness is associated with increased energetic costs, such as the reduction of foraging time or increase in energetic expenditure during flight responses. For example,

Table 1 Factors associated with flight initiation distances in black swans. DRD4 genotype (i.e. common or rare genotype), heterozygosity at eight microsatellite loci, starting distance and distance from water were included as independent variables in generalised linear mixed models, incorporating swan identity as a random factor (random effect variance $=0.092 \pm 0.033$, $Z=2.757, P=0.006)$

\begin{tabular}{lcl}
\hline Predictor variable & $F_{1,464}$ & $P$ \\
\hline DRD4 genotype & 5.192 & $\mathbf{0 . 0 2 3}$ \\
Microsatellite heterozygosity & 1.296 & 0.255 \\
Starting distance & 119.022 & $<\mathbf{0 . 0 0 1}$ \\
Distance from water & 1.041 & 0.308 \\
\hline
\end{tabular}

Significant effects are highlighted in bold individual Iberian wall lizards (Podarcis hispanica) which habituate more rapidly to a non-threatening stimulus, increase their body condition (a correlate of fitness in the species) more rapidly than individuals that habituate less [46].

The tendency of animals to be less wary around humans in areas experiencing high human traffic is a common pattern and may be related to various nonmutually exclusive factors. For example, habituation may occur when animals experience a repeated benign stimulation, resulting in a decrement in a certain behaviour, unrelated to sensory or motor fatigue [47]. An untested possibility is that swans at the urban site may have short flight initiation distances because humans are a very common and non-threatening stimulus at the site. Indeed, the difference in FIDs between swans with common and rare genotypes (8 vs $14 \mathrm{~m}$, respectively) was relatively small compared to the difference in FIDs between the urban and non-urban populations (13 vs $96 \mathrm{~m}$, respectively). This suggests that in addition to a possible effect of DRD4 variation on wariness, other factors, such as habituation to humans, contributed to site differences in wariness.

Second, these patterns may also arise due to local adaptations, with selection favouring certain genotypes at each site and little population mixing. However, the close proximity of the sites suggest that at least some migration between the sites occurs. This is further supported by the low, but possibly biologicallymeaningful, genetic differentiation at microsatellite loci. This reduces the likelihood of site-specific adaptations evolving. For example, between 2010 and 2012, eleven neck-collared swans captured at the urban site were observed at the non-urban site, at a distance of between $700 \mathrm{~m}$ and $84 \mathrm{~km}$ from the site of their previous sighting (mean $=27.7 \pm 24.6 \mathrm{SD} \mathrm{km}$; Mulder, unpublished data). Generally, one migrant per generation is sufficient to eliminate any population genetic differentiation [48], suggesting that local adaptation is not operating in these populations to a substantial degree. However, population differentiation at the neutral loci was significant, despite likely migration between the populations. Lastly, local site selection may be occurring. Black swans display strong inter-populational seasonal movements, which are related to various factors such as rainfall and stream flow [49]. The increased wariness of swans at the non-urban site, coupled with the higher frequency of DRD4 genotypes associated with wary behaviour at this site, suggest that more wary individuals settle in habitat with lower human usage. In contrast, bolder individuals may be more likely to settle at the urban site due to the greater resource abundance, including frequent anthropogenic feeding (van Dongen, personal 


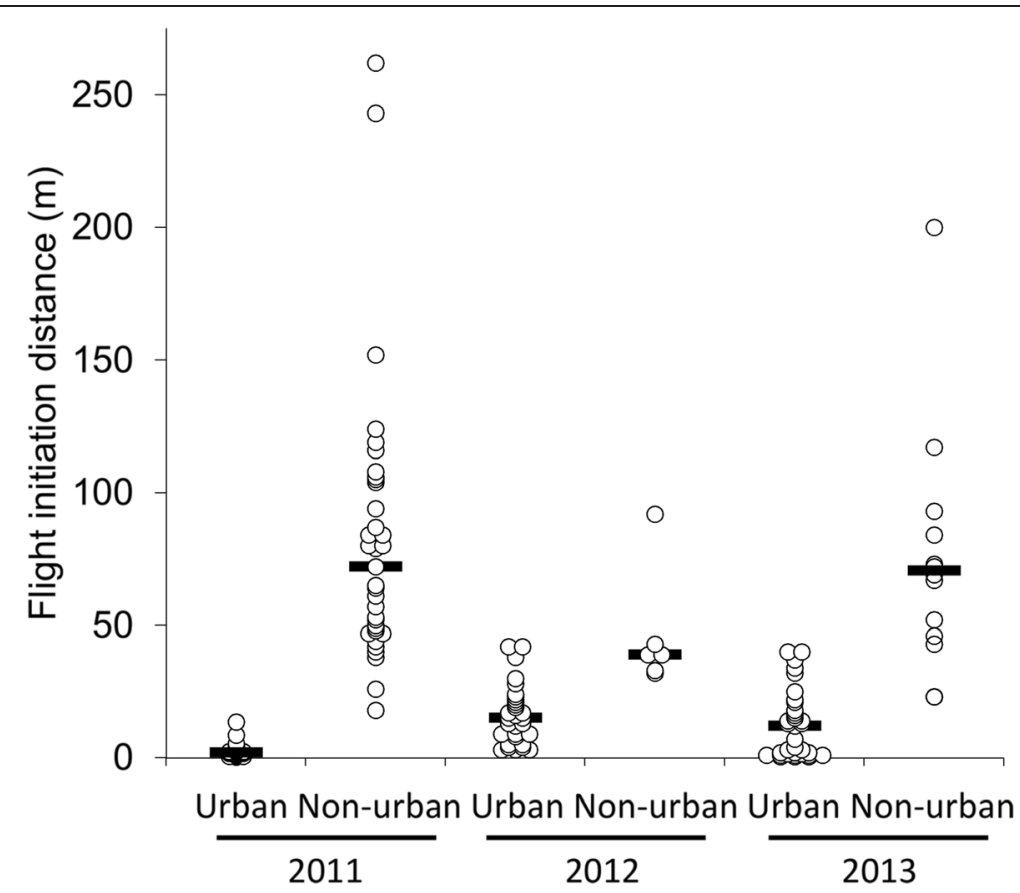

Fig. 4 Flight initiation distances of black swans between urban and non-urban swans, separated by year. Dots represent flight initiation distances for individual swans and bars represent median values

observation), or a potentially lower predation risk compared to rural areas [e.g. 8].

\section{Conclusions}

We have shown here that the fear of humans by black swans may be partly genetically-determined. Our findings also suggest that, in addition to learning or habituation, the lower responsiveness of wildlife in urban areas may be related to temperament-based local site selection. Our findings have important implications for conservation biology. First, the estimation of FIDs of threatened or sensitive species is an

Table 2 Abundance (\%) of the five DRD4 genotypes found in the urban and non-urban populations

\begin{tabular}{lll}
\hline & Population & \\
\cline { 2 - 3 } Genotype & Urban & $(n=20)$ \\
\hline \multirow{2}{*}{ AA } & $(n=80)$ & 60.0 \\
$\mathrm{AB}$ & 88.8 & 15.0 \\
$\mathrm{AC}$ & 3.8 & 10.0 \\
$\mathrm{AD}$ & 0.0 & 0.0 \\
$\mathrm{AE}$ & 5.0 & 10.0 \\
$\mathrm{BB}$ & 1.3 & 5.0 \\
\hline
\end{tabular}

important tool used by conservation managers interested in creating buffer zones around sensitive animal habitat [17]. However, within-species FID estimates can be highly labile and are associated with multiple factors associated with both the stimulus, focal individual and local environmental conditions [12, 35, 50, 51]. Our findings that individual FIDs may be partly genetically-determined, coupled with the high repeatability of FIDs, suggests that inter-individual variation in FID is greater than intra-individual variation. This justifies the estimation of FIDs of specific individuals based on single, or a small number of, approaches. In addition, population differences in DRD4 genotype frequencies may lead to variability between sites in wariness to humans and hence the need for sitespecific buffer zone sizes. The introduction of higher levels of human presence at previously undisturbed sites, such as when urban development occurs around wetlands or improved human access is provided, is likely to displace individuals who are more responsive to human presence. This is likely to effectively introduce local selection. Finally, our findings that certain animals may be able to cope better in heavily disturbed habitats have important implications for captive breeding programs of threatened species that will eventually be released in close proximity to humans. Individuals earmarked for reintroduction may be 
selected for specific temperaments more conductive to survival in the wild [1].

\section{Methods \\ Field work \\ Study sites}

Field work was conducted at two wetlands in Victoria, Australia, with contrasting visitor regimes: Albert Park Lake (APL; $37^{\circ} 50^{\prime} \mathrm{S}, 144^{\circ} 58^{\prime} \mathrm{E}$ ), an urban recreational park, which receives around 5 million visitors per annum $[43,52]$, and the Western Treatment Plant, Werribee (WTP; $37^{\circ} 54^{\prime} \mathrm{S}, 144^{\circ} 40^{\prime} \mathrm{E}$ ), a restricted-access wastewater processing site in a non-urban environment [53]. Black swans at APL exhibit relatively low responsiveness to humans [54], while those at WTP appear to be more wary [17]. The two sites are separated by about $30 \mathrm{~km}$. No hunting occurs at either site. The usual breeding season of this species extends from winter to spring [55].

Black swans were captured at APL between 2006 and 2013 and at WTP between November and December 2004. Birds were captured by hand and fitted with a metal leg band at WTP, and a metal leg band and a neck collar displaying a unique identification code at APL [42, 56]. Blood samples were taken from the tarsal vein for subsequent genetic analysis.

Flight initiation distances of swans at both sites were measured throughout the entire year between 2011 and 2013. To test whether polymorphisms at DRD4 and SERT were associated with flight initiation distances, we collated FIDs of neck-collared swans at the urban site. In addition, to test for population-level differences in FIDs between the urban and non-urban sites, we collected FIDs from any swan encountered at the non-urban site, regardless of whether we had previously captured the swan. Due to the large swan population at WTP, and our focus on comprehensive sampling at APL, we were unable to collect FID data on known swans at WTP for which we had a genetic sample.

Flight initiation distances were collected at both sites using methods outlined in detail elsewhere [51, 54, 57]. Briefly, we made standardised approaches to birds foraging on land. FIDs are positively associated with starting distance [58, 59], so we recorded SD for each approach. In addition, we recorded the distance of the focal individual from the edge of the shoreline because FIDs may be longer at greater distances from the nearest refuge [51]. An approach was made by identifying an individual that was foraging on land and walking directly towards it at a slow pace (approximately $1 \mathrm{~ms}^{-1}$ ). The distance from the researcher at which the swan initiated an escape response, either by walking, flying or swimming away, was recorded as the flight initiation distance. All distances were measured with an accuracy of one metre using a Bushnell Elite 1500 range finder. Multiple researchers collected FID data at each site, however inter-researcher differences in estimation of flight initiation distances of swans is low [54].

Up to 23 FIDs were collected per swan at the urban site (mean $=6.1 \pm 0.5 \mathrm{SE}$ FIDs/individual), while only one FID was likely collected per bird at the non-urban site. Only adult swans were included in this study. To ensure that we did not resample the same swan at the nonurban site, we monitored the location of individual birds that had already been sampled. In addition, the high abundance of the species at the site minimised the likelihood that the same swans were sampled on multiple days or years. When the focal individual was located within a flock of birds, we did not resample any of the other individuals within that flock. Flock size is known not to influence individual FIDs in this species [51].

Fieldwork was conducted under the following permits: Victoria University Animal Ethics Committee Permit AEETH 15/10, Deakin University Animal Ethics Committee Permits A48/2008 and B32/2012, the University of Melbourne Animal Ethics and Experimentation Committee of the Faculty of Science (register no. 0705887.4), DSE Scientific Permits, 10004585, 10004656 and 10005536 and a Western Treatment Plant Study Permit SP 08/02.

\section{Genetic analysis \\ DRD4 and SERT genotyping}

DNA was extracted from blood samples using the salting-out procedure [60]. We amplified 461 bp of the DRD4 gene using the primers F1-E3-DR4D (5'CCRCTSAACTACAACCGGCG-3') and R1-E3-DR4D [5'-YTCCCGGCCGTTGATCTTGG-3': 36]. We additionally amplified an exonic trinucleotide codon repeat in the SERT gene using the 6-FAM-labelled Sert_Ex1m_F2 primer (5'ATCTCCACACATTYCCCAGA-3') and Sert_Ex1m_R2 [5'-AGGAACCCTAAATCTGCCCTAC-3': 29]. Variation in the repeat number of this codon has previously been shown to correlate with individual differences in harm avoidance behaviour [29]. We therefore quantified the length of this fragment of all individuals. We additionally sequenced the SERT gene for 24 individuals to test for the presence of SNPs.

PCR was performed in $15.0 \mu \mathrm{l}$ reaction volumes containing the forward and reverse primer $(1.1 \mathrm{mM}$ each), 0.05 units of GoTaq DNA polymerase (Promega), 1x Colorless GoTaq Flexi Buffer, $3.3 \mathrm{mM} \mathrm{MgCl} 2$ (Promega), $0.2 \mathrm{mM}$ dNTPs and approximately $50 \mathrm{ng}$ of genomic DNA. PCRs were run on a BioRad Mycycler Thermocycler. For DRD4, an initial denaturation step $\left(95{ }^{\circ} \mathrm{C}\right.$, $3 \mathrm{~min}$ ) was followed by 35 cycles of $45 \mathrm{~s}$ at $95{ }^{\circ} \mathrm{C}, 1 \mathrm{~min}$ 
at $60{ }^{\circ} \mathrm{C}, 1 \mathrm{~min}$ at $72{ }^{\circ} \mathrm{C}$, and a final extension step for $5 \mathrm{~min}$ at $72{ }^{\circ} \mathrm{C}$. DRD4 fragments were commercially sequenced (Australian Genome Research Facility) in both directions and viewed in CLC Main Workbench 7.0.3 (CLC Bio). Only SNPs that were present in both the forward and reverse sequence for each individual were considered genuine. All others were assumed to be sequencing artefacts. Following [36], we then identified unique alleles that differed from all other alleles by at least one SNP and assigned genotypes to each individual based on the identity of their two alleles. The unique DRD4 alleles generated for this study were then submitted to GenBank [GenBank: KM390804-KM390808].

For SERT, an initial denaturation step $\left(94{ }^{\circ} \mathrm{C}, 5 \mathrm{~min}\right)$ was followed by 35 cycles of $30 \mathrm{~s}$ at $94{ }^{\circ} \mathrm{C}, 60 \mathrm{~s}$ at $53{ }^{\circ} \mathrm{C}$, $60 \mathrm{~s}$ at $72{ }^{\circ} \mathrm{C}$, and a final extension step for $15 \mathrm{~min}$ at $72{ }^{\circ} \mathrm{C}$. Fragment analysis of the SERT codon repeats was also conducted commercially (Australian Genome Research Facility) and results were viewed in GeneMarker 2.6.3 (SoftGenetics LLC). The SERT locus of 24 individuals was also commercially sequenced in both directions (Australian Genome Research Facility).

We confirmed correct amplification of the DRD4 and SERT genes via a BLASTP search [61] of the swan protein sequences in GenBank. The strength in similarity between protein sequences was assessed via the Evalues, with values closer to zero corresponding to greater sequence similarity [62].

\section{Microsatellite genotyping}

To control for heterozygosity-fitness correlations [63] that may result in artefactual associations between gene polymorphisms and FIDs, we also genotyped birds at eight microsatellite loci that were presumably neutrally-selected, including Cam3 and Cam9 [64], TTUCG5 [65], TSP.1.20.9 and TS.1.29.32 [66], Caudo24 [67]. We additionally amplified the Cam4 and Cam10 loci as described in [64], but with one modified primer per locus to increase the length of the amplified fragment (modified primers - Cam4L reverse primer: 5'-CCAAACCACTTACAACCATTG3'; Cam10L forward primer: 5'-M13-AATGGCAGTGGAATACAAAG-3'). PCR was performed for each locus as described in the above references and in [68]. Fragments were electrophoresed on a Beckman Coulter $8000 \mathrm{XL}$ automated sequencer. Fragment sizes were scored using an automated binning system in the Beckman Coulter 8000XL fragment analysis software, which were also confirmed visually. This binning system is well-established for these loci and has previously been used elsewhere for this species [64, 68]. We confirmed that all loci were under HardyWeinberg equilibrium using Cervus 3.0 [69].

\section{Statistical analyses}

Analyses on the repeatability of FIDs, and the association between FID and gene variation were conducted using data collected from APL alone. Analyses on population differences in FID, and in population genetic differentiation, were conducted using data from both APL and WTP.

Repeatability in flight initiation distances was estimated following [40], where repeatability is given by $r$ $=\frac{S_{A}^{2}}{S^{2}{ }_{W}+S_{A}^{2}}\left(S_{\mathrm{A}}\right.$ is the among-groups variance component and $S_{W}$ is the within-group variance component). We selected 105 swans for this analysis, for which we had two FID estimates for each individual that were collected within a few months of each other (mean time lapsed between first and second trial $=18.2 \pm 1.8$ SE days, $1-93$ days). As FID is positively associated with SD, we first regressed FID with SD across all individuals for each trial separately. We then used the residuals for each individual (ResFID) for the repeatability analysis. Thus, an individual with a positive residual had a longer FID than expected from its SD. We then tested whether the absolute difference in ResFID between the first and second trial correlated with time lapsed. We did not expect a linear relationship between FID difference and days lapsed, but instead expected more similar FIDs when less time had passed between FID estimates. The distribution of days lapsed was approximately bimodal, with a median of 10 days. We therefore tested whether the absolute difference in ResFIDs was greater for birds sampled more than 10 days apart. Similarly we tested whether the absolute difference in ResFID between trials varied according to whether the same researcher or two different researchers collected the two FID estimates for each individual.

As we found no interindividual variation at the SERT codon repeats, no further analyses were conducted for this gene. We translated all DRD4 alleles into protein sequences using CLC Main Workbench 7.0.3 (CLC Bio) to test whether alleles differed in synonymous or nonsynonymous base substitutions. However, for downstream analyses, we characterised differences between individuals based on genotypes and not protein sequences as synonymous base-pair substitutions may also result in changes in protein functionality [70]. In addition, synonymous substitutions may be associated with non-synonymous SNPS within other regions of the DRD4 gene (e.g. [44]).

For our analysis on the association between DRD4 genotypes and FID, we often had multiple estimates of FID for each individual. As FID may vary with multiple factors (e.g. SD and distance to the nearest refuge), we did not average multiple estimates per individual. Instead we included all FID data for all individuals and conducted 
generalised linear mixed modelling, incorporating swan identity as a random effect and FID as the dependent variable. As FID followed a gamma distribution for both populations and allele cohorts (i.e. 'common' vs 'rare' alleles), we used a log link for our analyses. Mixed models are additionally useful as they can be used for data with heterogeneous variances between groups [71, 72]. As the uneven distribution of alleles resulted in unequal samples sizes in our analyses on the effect of DRD4 genotype on FID, the possibility remains that certain individuals with rare alleles and extreme FIDs may bias the results. To minimise these effects, we grouped all rare alleles into one category to increase the robustness of the analysis (as opposed to treating each allelic variant as a separate group). Variances between these two groups were homogenous (Levene's test: $F_{1,478}=0.032$, $P=0.858$ ). Models include DRD4 genotype (i.e. 'common' or 'rare'), starting distance, the distance to the nearest refuge and microsatellite heterozygosity as predictor variables. Lastly, to quantify how well the model fitted the data, we calculated the percentage change in deviance between the focal model and the model containing only the intercept $[73,74]$.

To test for population differences in FID, we only included one randomly-selected FID estimate per individual swan. The analysis included 53 FIDs from the non-urban site and 93 from the urban site. Finally, genetic differentiation between populations was estimated at the DRD4 locus and neutral microsatellite loci by conducting an analyses of molecular variance in ARLEQUIN 3.5.1.2 [75]. Although $\mathrm{F}_{\mathrm{ST}}$ values cannot be directly compared between neutral microsatellites and other genetic loci [76], their quantification can still provide information on the degree of genetic differentiation between the two sites.

We conducted all non-genetic statistical analyses using SPSS 20.0 (SPSS, Chicago, Illinois, USA). Nonparametric tests were used when the assumption of data normality or homoscedasticity was not met. All data are presented as mean \pm SE. For GLMMs, we present predicted means $\pm \mathrm{SE}$.

\section{Abbreviations \\ APL: Albert Park Lake; DNA: Deoxyribonucleic acid; dNTPs: Deoxynucleotide triphosphates; DRD4: Dopamine receptor $\mathrm{D}_{4} ;$ FID: Flight initiation distance; $\mathrm{MgCl}_{2}$ : Magnesium chloride; PCR: Polymerase chain reaction; ResFID: Residual flight initiation distance; SD: Starting distance; SE: Standard error; SERT: Serotonin transporter; SNP: Single nucleotide polymorphism; WTP: Western Treatment Plant.}

\section{Competing interests}

The authors declare that they have no competing interests.

\section{Authors' contributions}

The study was designed by P-JG, MW, RM and RR and fieldwork was performed by P-JG, WVD and RM. WVD and P-JG conducted the laboratory work and WVD analysed the data. WvD wrote the manuscript. All authors contributed to and approved the final manuscript.

\section{Acknowledgements}

We thank the many volunteers who have assisted in fieldwork for this project and three anonymous referees for their comments on an earlier version of the manuscript. This study was funded by the Victoria University Central Research Grant Scheme.

\section{Author details}

${ }^{1}$ Applied Ecology Research Group and Institute for Sustainability and Innovation, College of Engineering and Science, Victoria University-Footscray Park Campus, PO Box 14428, Melbourne MC, VIC 8001, Australia. ${ }^{2}$ Centre for Integrative Ecology, School of Life and Environmental Sciences, Faculty of Science, Engineering and the Built Environment, Deakin University, 221 Burwood Highway, Burwood, VIC 3125, Australia. ${ }^{3}$ Department of Zoology, University of Melbourne, Melbourne, VIC 3010, Australia.

Received: 21 March 2015 Accepted: 4 November 2015

Published online: 11 December 2015

\section{References}

1. Stamps JA. Habitat selection by dispersers: integrating proximate and ultimate approaches. In: Clobert J, Danchin E, Dhondt AA, Nichols JD, editors. Dispersal. Oxford: Oxford University Press; 2001. p. 230-42.

2. Piper WH. Making habitat selection more "familiar": a review. Behav Ecol Sociobiol. 2011;65:1329-51.

3. Morris DW. Adaptation and habitat selection in the eco-evolutionary process. Proc R Soc Lond B. 2011;278:2401-11.

4. Schlaepfer MA, Runge MC, Sherman PW. Ecological and evolutionary traps. Trends Ecol Evol. 2002;17:474-80.

5. Robertson BA, Rehage JS, Sih A. Ecological novelty and the emergence of evolutionary traps. Trends Ecol Evol. 2013;28:552-60.

6. Lindsey KJ, Adams CE. Urban wildlife management. Boca Raton: CRC Press; 2006.

7. Jones DN, James RS. Feeding birds in our towns and cities: a global research opportunity. J Avian Biol. 2008;39:265-71.

8. Møller AP. Urban areas as refuges from predators and flight distance of prey. Behav Ecol. 2012;23:1030-5.

9. Markovchick-Nicholls L, Regan HM, Deutschman DH, Widyanata A, Martin B, Noreke $L$, et al. Relationships between human disturbance and wildlife land use in urban habitat fragments. Cons Biol. 2008;22:99-109.

10. Chapman R, Jones DN. Just feeding the ducks: quantifying a common wildlife-human interaction. Sunbird. 2009;39:19-28.

11. McCleery RA. Changes in fox squirrel anti-predator behaviors across the urban-rural gradient. Landscape Ecol. 2009;24:483-93.

12. Møller AP. Flight distance of urban birds, predation, and selection for urban life. Behav Ecol Sociobiol. 2008;63:63-75.

13. Magle S, Zhu J, Crooks KR. Behavioral responses to repeated human intrusion by black-tailed prairie dogs (Cynomys ludovicianus). J Mammal. 2005:86:524-30.

14. Atwell JW, Cardoso GC, Whittaker DJ, Campbell-Nelson S, Robertson KW, Ketterson ED. Boldness behavior and stress physiology in a novel urban environment suggest rapid correlated evolutionary adaptation. Behav Ecol. 2012;23:960-9.

15. Sol D, Lapiedra O, Gonzalez-Lagos C. Behavioural adjustments for a life in the city. Anim Behav. 2013;85:1101-12.

16. Møller AP. Interspecific variation in fear responses predicts urbanization in birds. Behav Ecol. 2010;21:365-71.

17. Weston MA, McLeod EM, Blumstein DT, Guay P-J. A review of flightinitiation distances and their application to managing disturbance to Australian birds. Emu. 2012;112:269-86.

18. Wolf M, Weissing FJ. Animal personalities: consequences for ecology and evolution. Trends Ecol Evol. 2012;27:452-61.

19. Sih A, Cote J, Evans M, Fogarty S, Pruitt J. Ecological implications of behavioural syndromes. Ecol Lett. 2012;15:278-89.

20. Sih A, Bell AM, Johnson JC, Ziemba RE. Behavioral syndromes: an integrative overview. Q Rev Biol. 2004;79:241-77.

21. Carrete M, Tella JL. Individual consistency in flight initiation distances in burrowing owls: a new hypothesis on disturbance-induced habitat selection. Biol Lett. 2010;6:167-70.

22. van Oers K, de Jong G, van Noordwijk AJ, Kempenaers B, Drent PJ. Contribution of genetics to the study of animal personalities: a review of case studies. Behaviour. 2005;142:1185-206. 
23. Nussey DH, Wilson AJ, Brommer JE. The evolutionary ecology of individual phenotypic plasticity in wild populations. J Evol Biol. 2007;20:831-44

24. Sih A. Effects of early stress on behavioral syndromes: an integrated adaptive perspective. Neurosci Biobehav Rev. 2011;35:1452-65.

25. Kluger AN, Siegfried Z, Ebstein RP. A meta-analysis of the association between DRD4 polymorphism and novelty seeking. Mol Psychiatr. 2002;7:712-7.

26. Garpenstrand H, Annas P, Ekblom J, Oreland L, Fredrikson M. Human fear conditioning is related to dopaminergic and serotonergic biological markers. Behav Neurosci. 2001;115:358-64.

27. Guo G, North KE, Gorden-Larsen P, Bulik CM, Choi S. Body mass, DRD4, physical activity, sedentary behavior, and family socioeconomic status: the add health study. Obesity. 2007;15:1199-206.

28. Timm K, Tilgar V, Saag P. DRD4 gene polymorphism in great tits: gender-specific association with behavioural variation in the wild. Behav Ecol Sociobiol. 2015;69:729-35

29. Mueller JC, Partecke J, Hatchwell BJ, Gaston KJ, Evans KL. Candidate gene polymorphisms for behavioural adaptations during urbanization in blackbirds. Mol Ecol. 2013;22:3629-37.

30. Callier S, Snapyan M, Le Crom S, Prou D, Vincent JD, Vernier P. Evolution and cell biology of dopamine receptors in vertebrates. Biol Cell. 2003:95:489-502.

31. Canli T, Lesch KP. Long story short: the serotonin transporter in emotion regulation and social cognition. Nat Neurosci. 2007:10:1103-9.

32. Craig IW, Halton KE. Genetics of human aggressive behavior. Hum Genet. 2009;126:101-13.

33. Riyahi S, Sanchez-Delgado M, Calafell F, Monk D, Senar JC. Combined epigenetic and intraspecific variation of the DRD4 and SERT genes influence novelty seeking behavior in great tit Parus major. Epigenetics. 2015;10:516-25.

34. Melke J. Serotonin transporter gene polymorphisms and mental health. Curr Opin Psychiatr. 2003;16:215-20.

35. Garamszegi LZ, Mueller JC, Marko G, Szasz E, Zsebok S, Herczeg G, et al. The relationship between DRD4 polymorphisms and phenotypic correlations of behaviors in the collared flycatcher. Ecol Evol. 2014;4:1466-79.

36. Gillingham MAF, Bechet A, Geraci J, Wattier R, Dubreuil C, Cezilly F. Genetic polymorphism in dopamine receptor D4 is associated with early body condition in a large population of greater flamingos, Phoenicopterus roseus. Mol Ecol. 2012;21:4024-37.

37. Fidler AE, van Oers K, Drent PJ, Kuhn S, Mueller JC, Kempenaers B. Drd4 gene polymorphisms are associated with personality variation in a passerine bird. Proc R Soc Lond B. 2007;274:1685-91.

38. Møller AP. Life history, predation and flight initiation distance in a migratory bird. J Evol Biol. 2014;27:1105-13.

39. Dohm MR. Repeatability estimates do not always set an upper limit to heritability. Funct Ecol. 2002;16:273-80.

40. Lessells CM, Boag PT. Unrepeatable repeatabilities - a common mistake. Auk. 1987;104:116-21.

41. Braithwaite LW. Black swan colour marking program. Aust Bird Bander. 1966;4:78-9.

42. Mulder RA, Guay P-J, Wilson M, Coulson G. Citizen science: recruiting residents for studies of tagged urban wildlife. Wildlife Res. 2010;37:440-6.

43. Payne CJ, Jessop TJ, Guay P-J, Johnstone M, Feore M, Mulder RA Population, behavioural and physiological responses of an urban population of black swans to an intense annual noise event. PLoS ONE. 2012;7, e45014

44. Mueller JC, Korsten P, Hermannstaedter C, Feulner T, Dingemanse NJ, Matthysen E, et al. Haplotype structure, adaptive history and associations with exploratory behaviour of the DRD4 gene region in four great tit (Parus major) populations. Mol Ecol. 2013;22:2797-809.

45. Stankowich T, Blumstein DT. Fear in animals: a meta-analysis and review of risk assessment. Proc R Soc Lond B. 2005;272:2627-34.

46. Rodriguez-Prieto I, Martin J, Fernandez-Juricic E. Habituation to low-risk predators improves body condition in lizards. Behav Ecol Sociobiol. 2010;64:1937-45.

47. Rankin CH, Abrams T, Barry RJ, Bhatnagar S, Clayton DF, Colombo J, et al Habituation revisited: an updated and revised description of the behavioral characteristics of habituation. Neurobiol Learn Mem. 2009;92:135-8.

48. Wang J. Application of the one-migrant-per-generation rule to conservation and management. Cons Biol. 2004;18:332-43.
49. Chambers LE, Loyn RH. The influence of climate variability on numbers of three waterbird species in Western Port, Victoria, 1973-2002. Int J Biometeorol. 2006;50:292-304.

50. McLeod EM, Guay P-J, Taysom AJ, Robinson RW, Weston MA. Buses, cars, bicycles and walkers: The influence of the type of human transport on the flight responses of waterbirds. PLoS ONE. 2013;8, e82008.

51. Guay P-J, Lorenz RDA, Robinson RW, Symonds MRE, Weston MA. Distance from water, sex and approach direction influence flight distances among habituated black swans. Ethology. 2013;119:552-8.

52. Dear EJ, Guay P-J, Robinson RW, Weston MA. Distance from shore positively influences alert distance in three wetland birds. Wetl Ecol Manag. 2015;23:315-8

53. Loyn RH, Rogers DI, Swindley RJ, Stamation K, Macak P, Menkhorst P. Waterbird monitoring at the Western Treatment Plant, 2000-12: The effects of climate and sewage treatment processes on waterbird populations. Heidelberg: Arthur Rylah Institute for Environmental Research Technical Report Series No. 256: Department of Environment and Primary Industries; 2014.

54. Guay P-J, McLeod EM, Cross R, Formby AJ, Maldonado SP, Stafford-Bell RE, et al. Observer effects occur when estimating alert but not flight-initiation distances. Wildlife Res. 2013:40:289-93.

55. Braithwaite LW. Ecological studies of the black swan IV. The timing and success of breeding on two nearby lakes on the southern tablelands of New South Wales. Wildlife Res. 1982;9:261-75.

56. Guay P-J, Mulder RA. Do neck-collars affect the behaviour and condition of black swans (Cygnus atratus)? Emu. 2009;109:248-51.

57. Guay P-J, Weston MA, Symonds MRE, Glover HK. Brains and bravery: little evidence of a relationship between brain size and flightiness in shorebirds. Austral Ecol. 2013;38:516-22.

58. Blumstein DT. Flight-initiation distance in birds is dependent on intruder starting distance. J Wildlife Manage. 2003;67:852-7.

59. Dumont F, Pasquaretta C, Réale D, Bogliani G, von Hardenberg A. Flight initiation distance and starting distance: biological effect or mathematical artefact? Ethology. 2012;118:1051-62.

60. Bruford MW, Hanotte O, Brookfield JFY, Burke T. Single locus and multi-locus fingerprinting. In: Hoelzel AR, editor. Molecular genetics analysis of population - a molecular approach. Oxford: IRL Press; 1992. p. 227-9.

61. Altschul SF, Gish W, Miller W, Myers EW, Lipman DJ. Basic local alignment search tool. J Mol Biol. 1990;215:403-10.

62. Altschul SF, Madden TL, Schäffer AA, Zhang J, Zhang Z, Miller W, et al. Gapped BLAST and PSI-BLAST: a new generation of protein database search programs. Nucleic Acids Res. 1997;25:3389-402.

63. Szulkin M, Bierne N, David P. Heterozygosity-fitness correlations: a time for reappraisal. Evolution. 2010;64:1202-17.

64. Carew PJ, Adcock GJ, Mulder RA. Microsatellite loci for paternity assessment in the black swan (Cygnus atratus: Aves). Mol Ecol Notes. 2003;3:1-3.

65. Cathey JC, DeWoody JA, Smith LM. Microsatellite markers in Canada geese (Branta canadensis). J Hered. 1998;89:173-5.

66. St John J, Ransler FA, Quinn TW, Oyler-McCance SJ. Characterization of microsatellite loci isolated in trumpeter swan (Cygnus buccinator). Mol Ecol Notes. 2006:6:1083-5.

67. Huang YH, Tu JF, Cheng XB, Tang B, Hu XX, Liu ZL, et al. Characterization of 35 novel microsatellite DNA markers from the duck (Anas platyrhynchos) genome and cross-amplification in other birds. Genet Sel Evol. 2005;37:455-72

68. Kraaijeveld K, Carew PJ, Billing T, Adcock GJ, Mulder RA. Extra-pair paternity does not result in differential sexual selection in the mutually ornamented black swan (Cygnus atratus). Mol Ecol. 2004;13:1625-33.

69. Kalinowski S, Taper M, Marshall T. Revising how the computer program CERVUS accommodates genotyping error increases success in paternity assignment. Mol Ecol. 2007;16:1099-106.

70. Sauna ZE, Kimchi-Sarfaty C. Understanding the contribution of synonymous mutations to human disease. Nat Rev Genet. 2011;12:683-91.

71. Bolker BM, Brooks ME, Clark CJ, Geange SW, Poulsen JR, Stevens MHH, et al. Generalized linear mixed models: a practical guide for ecology and evolution. Trends Ecol Evol. 2009:24:127-35.

72. Piepho H-P. Data transformation in statistical analysis of field trials with changing treatment variance. Agron J. 2009:101:865-9.

73. Sodhi NS, Lee TM, Koh LP, Brook BW. A meta-analysis of the impact of anthropogenic forest disturbance on southeast Asia's biotas. Biotropica. 2009:41:103-9. 
74. Fordham DA, Akcakaya HR, Araujo MB, Elith J, Keith DA, Pearson R, et al. Plant extinction risk under climate change: are forecast range shifts alone a good indicator of species vulnerability to global warming? Glob Change Biol. 2012;18:1357-71.

75. Excoffier L, Lischer HEL. Arlequin suite version 3.5: a new series of programs to perform population genetics analyses under Linux and Windows. Mol Ecol Resour. 2010;10:564-7.

76. Coates BS, Sumerford DV, Miller NJ, Kim KS, Sappington TW, Siegfried BD, et al. Comparative performance of single nucleotide polymorphism and microsatellite markers for population genetic analysis. J Hered. 2009;100:556-64.

\section{Submit your next manuscript to BioMed Central} and take full advantage of:

- Convenient online submission

- Thorough peer review

- No space constraints or color figure charges

- Immediate publication on acceptance

- Inclusion in PubMed, CAS, Scopus and Google Scholar

- Research which is freely available for redistribution 